\title{
Neuromuscular Function in Survivors of the Acute Respiratory Distress Syndrome
}

\author{
Michael J. Angel, Vera Bril, Patrick Shannon, Margaret S. Herridge
}

\begin{abstract}
Background: Survivors of acute respiratory distress syndrome (ARDS) report generalized weakness and reduced exercise tolerance up to two years following discharge from the intensive care unit (ICU). Persistent neuromuscular complications of ARDS may contribute to the functional disability observed in these patients. Methods: Sixteen ARDS survivors underwent comprehensive neurological evaluation and standardized electrodiagnostic testing 6 to 24 months after ICU discharge. Four of these patients agreed to open muscle biopsy. Results: Seven of sixteen patients had clinically significant focal compressive mononeuropathies. Electrodiagnostic testing failed to reveal any changes attributable to critical illness polyneuropathy or myopathy. All four muscle biopsies were abnormal, and although the pathological features were structurally non-specific, the presence of an acquired myopathy remains possible. Four patients had persistent mixed sensory complaints but had normal electrodiagnostic evaluation. Conclusions: The high frequency of mononeuropathies highlights the need for vigilance in daily ICU care. The findings also suggest that complaints of weakness and reduced exercise capacity in ARDS survivors may be related to combined effects of compressive neuropathies and generalized longstanding structural changes in muscle and may support an organic basis for longterm functional disability.
\end{abstract}

RÉSUMÉ: Fonction neuromusculaire chez les survivants du syndrome de détresse respiratoire aigu. Contexte : Les survivants du syndrome de détresse respiratoire aiguë (SDRA) se plaignent d'une faiblesse généralisée et d'une diminution de la tolérance à l'effort plus de deux ans après leur congé de l'unité de soins intensifs. Il est possible que des complications neuromusculaires persistantes du SDRA contribuent à l'invalidité fonctionnelle observée chez ces patients. Méthodes : Seize survivants du SDRA ont subi une évaluation neurologique complète et un électrodiagnostic standardisé, 6 à 24 mois après leur sortie de l'unité de soins intensifs. Quatre de ces patients ont consenti à subir une biopsie musculaire ouverte. Résultats : Sept des seize patients avaient des mononeuropathies compressives focales qui étaient significatives au point de vue clinique. L'électrodiagnostic n'a pas révélé de changements attribuables à une polyneuropathie ou à une myopathie reliée à une maladie grave. Les quatre biopsies musculaires étaient anormales et, bien que les anomalies anatomopathologiques n'étaient pas spécifiques au point de vue structural, la présence d'une myopathie acquise demeure possible. Quatre patients se plaignaient de troubles sensitifs mixtes persistants, mais leur évaluation électrodiagnostique était normale. Conclusions : La fréquence élevée des mononeuropathies démontre qu'il faut être vigilant en ce qui concerne les soins quotidiens à l'unité de soins intensifs. Nos constatations suggèrent également que la faiblesse et la diminution de la tolérance à l'effort chez les survivants du SDRA pourraient être reliées aux effets combinés de neuropathies compressives et de changements structuraux généralisés présents de longue date au niveau des muscles, et que l'invalidité fonctionnelle prolongée a une base organique chez ces patients.

Can. J. Neurol. Sci. 2007; 34: 427-432

Although the survival rate of patients with acute respiratory distress syndrome (ARDS) has continued to improve, ${ }^{1}$ the ongoing morbidity and reduced quality of life in survivors remains significant. ${ }^{2}$ Several investigators have reported impaired physical functioning in long-term ARDS survivors but the main determinants of this disability have remained unclear., ${ }^{2,3}$ A recent prospective cohort study evaluating long-term outcomes in survivors of $\mathrm{ARDS}^{4}$ noted that ARDS survivors had evidence of muscle wasting and weakness up to two years following intensive care unit (ICU) discharge. This group also demonstrated that patients achieve only $66 \%$ of their predicted six minute walk distance at one year compared to sex and agematched controls. The absence of systemic corticosteroid treatment, the absence of organ dysfunction acquired during the ICU stay and rapid resolution of lung injury and multiple organ dysfunction were associated with better exercise capacity during

From the Department of Medicine, Division of Neurology (MJA, VB), Department of Pathology, Division of Neuropathology (PS), Department of Medicine, Divisions of Respiratory and Critical Care Medicine (MSH), University Health Network, University of Toronto, Toronto, Ontario, Canada.

RECEIVED APRIL 3, 2004. ACCEPTED IN FINAL FORM JUNE 2, 2007. Reprint requests to: Vera Bril, 13N-1382, TGH, University Health Network, 585 University Ave., Toronto, Ontario, M5G 2N2, Canada. 
the one-year follow-up. In light of the observed muscle wasting and weakness, these authors hypothesized that ICU-acquired weakness may be an important contributor to long-term functional disability.

Critical illness neuropathy and myopathy may result in prolonged mechanical ventilation and can cause quadriparesis..$^{5-9}$ In the last two decades, these conditions have been increasingly well described in the acute ICU phase of critical illness. ${ }^{10,11} \mathrm{De}$ Jonghe and colleagues recently described a $25 \%$ incidence of ICU acquired paresis (ICUAP) in patients remaining on the mechanical ventilator for seven or more days. ${ }^{12}$ All of the ICUAP patients had a sensorimotor axonopathy and those who underwent muscle biopsy had independent muscle involvement. Fletcher and coworkers performed neurophysiological testing on 22 patients who had spent $\geq 28$ days in the ICU. They found evidence of a chronic partial denervation of muscle consistent with prior critical illness polyneuropathy in $>90 \%$ of patients at a median of 43 months following ICU discharge. ${ }^{13}$ They found little evidence of a myopathy at that time. Both myopathy and neuropathy are considered to be monophasic, with a good longterm prognosis following recovery from the underlying critical illness. ${ }^{9}$ Critical illness polyneuropathy, and myopathy are not uncommon in patients with ARDS,${ }^{14}$ however, the long-term persistence of neuromuscular disorders in patients who had no clinical history of frank ICU-acquired paresis associated with ARDS has not been well described and it remains unclear whether neuropathy, myopathy or a combination of these contributes to the reported functional disability in these patients. Here we report on the long-term neuromuscular function in a symptomatic subset of 16 patients recruited from a prospective cohort of 109 ARDS survivors.

\section{MeTHODS}

\section{Patient Ascertainment}

Sixteen patients were recruited from the ARDS Outcomes study cohort. ${ }^{4}$ Patients were eligible for enrollment if they were at least 18 years of age, had a $\mathrm{PaO} 2: \mathrm{FiO} 2$ ratio of 200 or less while receiving mechanical ventilaton with a positive endexpiratory pressure of at least $5 \mathrm{~cm}$ of water, evidence of airspace changes in all four quadrants on chest radiography, and an identifiable risk factor for the acute respiratory distress syndrome. Patients were excluded if they were immobile before being admitted to the ICU, had a history of pulmonary resection, or had a neurologic or psychiatric disease that would preclude ambulation sufficient to complete the six minute walk test. Inclusion criteria for the neuromuscular review were as follows: all patients who complained of disabling functional limitation during the follow-up visit and/or who exhibited decreased muscle power or abnormal neurological findings on physical examination of the extremities as evaluated by a non-neurologist physician (MH) at or following the six-month follow-up appointment were referred for complete neuromuscular assessment. The study was approved by the Research Ethics Board of the University Health Network (UHN).

\section{Clinical Evaluation}

A detailed pre- and post ARDS medical history was obtained for each patient. This documented pre-morbid and co-morbid disease and post ICU-discharge neuromuscular symptoms.
Duration of ventilation and use of steroids and/or neuromuscular blocking agents were recorded. Each patient underwent a complete neurological examination, followed by a standardized electrodiagnostic examination in follow-up after discharge from hospital. Abnormal findings on neurological examination were recorded as either focal, diffuse or both in the case of the motor system. Sensory findings were described by distribution and modalities affected. Four of the patients agreed to undergo an open muscle biopsy as part of their neuromuscular diagnostic evaluation. The standard neurological examination was directed towards the neuromuscular system with a complete evaluation of the cranial nerves, muscle bulk, tone and strength graded on the British MRC scale of 0 (paralysis) to 5 (normal strength), deep tendon reflexes, and testing sensory function of the primary modalities of light touch, position, $128 \mathrm{~Hz}$ vibration, pinprick (disposable Neurotip), and temperature (cold tuning fork). The distribution of deficits was evaluated as being either focal, or diffuse.

\section{Electrodiagnostic Tests}

Standardized electrodiagnostic studies were done in all patients using the Keypoint device (Medtronic, Mississauga, Canada). Conventional nerve conduction studies of median, ulnar, peroneal and sural nerves were done. Care was taken to measure and record distances accurately, and temperature was controlled at $>32^{\circ} \mathrm{C}$ in the upper limb and $>31^{\circ} \mathrm{C}$ in the lower limb. Conventional electromyographic examination of the Deltoid, First Dorsal Interosseous, Quadriceps and Tibialis Anterior muscles was done. Age and sex-matched reference values were used.

\section{Quantitative Sensory Testing}

All patients had vibration perception thresholds (VPT) measured using the Neurothesiometer (Horwell Scientific, London, UK) and the method of limits testing paradigm. Vibration perception thresholds was obtained from the pulp surface of the index finger and great toe bilaterally. Age- and gender-matched reference values were used.

\section{Muscle Biopsy and Biochemical Tests}

An open muscle biopsy was performed by a surgeon on the quadriceps muscle in four patients. The procedures were done in the day surgery unit of the UHN. Muscle biopsies were divided, epoxy- and paraffin-embedded, and quick frozen. Histological, histochemical and ultrastructural investigations were carried out according to standard protocol. Briefly, studies for oxidative enzymes (succinic dehydrogenase [SDH], nicotinic acid dehydrogenase [NADH]), myosin ATPases at varying $\mathrm{pH}$ levels, glycogen, neutral lipid and connective tissue elements were performed on all biopsies in conjunction with electron microscopic examination.

All patients had complete blood count (CBC), erythrocyte sedimentation rate (ESR), thyroid stimulating hormone (TSH), creatine kinase $(\mathrm{CK})$ and lactate serum levels measured as part of the neurological evaluation.

\section{ReSUlts}

Sixteen patients (10 male, 6 female) were evaluated for this study with ages ranging from 30 to 59 years (median 48). Table 
Table 1: Characteristics of ARDS Patients at Enrollment and During the ICU Course

\begin{tabular}{|c|c|c|c|}
\hline & $\begin{array}{l}\text { Neuromuscular } \\
\text { sample }(n=16)\end{array}$ & $\begin{array}{l}\text { ICU Cohort }^{4} \\
\quad(n=109)\end{array}$ & P-value * \\
\hline Median Age (IQR) & $48(39-55)$ & $46(36-58)$ & 1.0 \\
\hline Male Gender (\%) & $10(63 \%)$ & $63(58 \%)$ & 0.7 \\
\hline Median APACHE II $\dagger$ (IQR) & $25(19-29)$ & $23(17-28)$ & 0.5 \\
\hline Median Maximum LIS $\ddagger$ (IQR) & $3.8(3.2-4.0)$ & $3.7(3.0-4.0)$ & 0.5 \\
\hline Median Maximum MODS§ (IQR) & $11.5(10.5-14.5)$ & $11.0(9.0-13.0)$ & 0.4 \\
\hline \multicolumn{4}{|l|}{ ARDS Risk Factor } \\
\hline Pneumonia & $8(50 \%)$ & $57(52 \%)$ & 0.9 \\
\hline Sepsis/SIRS & $9(56 \%)$ & $45(41 \%)$ & 0.3 \\
\hline Trauma/Burns & $2(13 \%)$ & $24(22 \%)$ & 0.4 \\
\hline Pancreatitis & $2(13 \%)$ & $9(8 \%)$ & 0.6 \\
\hline Other & $5(31 \%)$ & $38(35 \%)$ & 0.8 \\
\hline $\begin{array}{l}\text { Any Exposure to Sysemic } \\
\text { Corticosteroid (\%) }\end{array}$ & $6(38 \%)$ & $39(36 \%)$ & 0.9 \\
\hline $\begin{array}{l}\text { Any Exposure to Neuromuscular } \\
\text { Blockers (\%) }\end{array}$ & $11(69 \%)$ & $60(55 \%)$ & 0.3 \\
\hline Median ICU Length of Stay (IQR) & $36(12-52)$ & $25(14-44)$ & 0.6 \\
\hline $\begin{array}{l}\text { Median months to neuromuscular } \\
\text { testing from discharge from ICU } \\
\text { (IQR) }\end{array}$ & $12(8-16)$ & - & \\
\hline
\end{tabular}

IQR : Intraquartile Range; *Wilcoxon for continuous variables; $\Pi^{2}$ for categorical variables. $\uparrow$ APACHE denotes Acute Physiology, Age, and Chronic Health Evaluation. Scores can range from 0 to 71; higher scores indicate more severe illness. $\ddagger$ LIS denotes Lung Injury Score. Scores can range from 0 to 4; higher scores indicate more severe lung injury. §MODS denotes Multiple Organ Dysfunction Score. Scores can range from 0 to 24; higher scores indicate more severe multiple organ dysfunction. $\|$ proportions do not add to $100 \% .47 \%$ of patients had 2 or more risk factors. $42 \%$ had both direct and indirect risk factors; SIRS: systemic inflammatory response syndrome.

I summarizes the demographic profile of these patients. All patients were intubated and mechanically ventilated. The duration of the ICU stay ranged from 5 to 150 days (mean 47.5 \pm 39.4 d). Co-morbid conditions in the ICU included sepsis $(\mathrm{n}=7)$, acute renal failure $(\mathrm{n}=4)$, pancreatitis $(\mathrm{n}=2)$, pulmonary embolism $(n=1)$, disseminated intravascular coagulation $(n=1)$, and intraabdominal hemorrhage $(n=1)$. Premorbid illnesses included type 2 diabetes $(n=5)$, nemaline myopathy $(n=1)$, hypothyroidism $(\mathrm{n}=1)$ and chronic pancreatitis $(\mathrm{n}=1)$. Six patients had exposure to systemic corticosteroids. Eleven of the patients received non-depolarizing neuromuscular blockade at some time during their ICU stay. The duration of follow-up ranged from 6 to 24 months (mean $10.9 \pm 5.6 \mathrm{SD}$ m) following ICU discharge.

Table 2 outlines the results of neurological evaluation. Motor symptoms were reported in 12 of the 16 patients. Patients complained of isolated focal weakness $(n=1)$, generalized weakness $(n=6)$, both focal and generalized weakness $(n=3)$, or no motor symptoms at all $(\mathrm{n}=6)$. Motor exam revealed normal tone, with no fasciculations in any of the patients' muscles.
Examination of strength revealed proximal/ diffuse weakness in five patients, focal weakness in three patients (superimposed on more diffuse weakness in one, and normal strength in eight patients. Reflexes were symmetric and normal in all patients. Plantar responses were symmetric and downgoing in all patients. Sensory symptoms included limb pain $(\mathrm{n}=5)$, numbness and tingling $(n=7)$, hyperesthesia $(n=1)$ and cool toes $(n=1)$. Physical examination revealed sensory abnormalities in nine patients. Table 3 summarizes the clinical and diagnostic findings.

\section{Electrodiagnostic Results}

\section{Nerve Conduction Studies}

Two patients had polyneuropathy, one of whom had preexistent diabetic neuropathy documented one-two years preARDS. Six patients had focal abnormalities of nerve conduction (mononeuropathies); peroneal nerve palsy $(\mathrm{n}=4)$, and ulnar nerve palsy $(n=2)$. One had diffuse changes and motor nerve conduction tests in the remaining eight patients were normal.

\section{Electromyography}

Two of sixteen patients had myopathic changes on their electromyographic studies. Eight of sixteen patients had chronic neurogenic changes, six of whom had mononeuropathies with

Table 2: Summary of the Neurological, Biochemical and Pathological Findings in 16 Long term ARDS Survivors

\begin{tabular}{lll}
\hline Finding & & N \\
\hline Persistent Symptoms & Motor & 12 \\
\cline { 2 - 3 } Neurological Deficits & Sensory & 12 \\
& Motor & 8 \\
Pattern of Weakness & Diffuse (>proximal) & 5 \\
& Focal & 4 \\
& Both & 1 \\
Abnormal & None & 6 \\
Electrodiagnostics & Motor or Sensory & 10 \\
Myopathic EMG & & \\
Abnormal VPT & & 2 \\
Muscle biopsy & & 2 \\
Abnormal muscle & & 4 \\
biopsy & & 4 \\
CK elevation & & 0 \\
\hline
\end{tabular}

$\mathrm{CK}=$ creatine kinase; diffuse $(>$ proximal $)=$ weakness includes both proximal and distal muscle groups; VPT = vibration perception threshold. 
Table 3: Summary of Clinical and Diagnostic Findings of 16 Longterm Survivors of ARDS

\begin{tabular}{|c|c|c|c|c|c|c|c|c|c|}
\hline Patient & $\begin{array}{l}\text { Age } \\
\mathrm{M} / \mathrm{F}\end{array}$ & ICU Diagnosis & $\begin{array}{l}\text { Pre- ICU } \\
\text { Diagnosis }\end{array}$ & Steroids & $\mathrm{F} / \mathrm{U}$ & Symptoms & Electrodiagnostics & VPT & Dx \\
\hline 1 & $48 / \mathrm{M}$ & $\begin{array}{l}\text { ARDS, } \\
\text { RF,sepsis }\end{array}$ & Pneumonia & No & $10 \mathrm{~m}$ & Foot drop & $\begin{array}{l}\text { Conduction block peroneal nerve } \\
\text { at the knee; neurogenic MUAP } \\
\text { tibialis anterior muscle; chronic } \\
\text { neurogenic MUAP hands/feet }\end{array}$ & Normal & $\begin{array}{l}\text { Focal compressive } \\
\text { peroneal palsy; } \\
\text { Polyneuropathy }\end{array}$ \\
\hline 2 & $41 / \mathrm{M}$ & ARDS & $\begin{array}{l}\text { Nemaline } \\
\text { myopathy }\end{array}$ & No & $6 \mathrm{~m}$ & $\begin{array}{l}\text { Weak hands, } \\
\text { diffuse weakness }\end{array}$ & $\begin{array}{l}\text { Myopathic units, Conduction } \\
\text { block ulnar nerve across elbow, } \\
\text { neurogenic MUAP ulnar muscles }\end{array}$ & Normal & $\begin{array}{l}\text { Focal compressive ulnar } \\
\text { neuropathy; myopathy } \\
\text { (pre-morbid) }\end{array}$ \\
\hline 3 & $59 / \mathrm{M}$ & $\begin{array}{l}\text { ARDS, liver tx, } \\
\text { abscess }\end{array}$ & $\begin{array}{l}\text { DM II, } \\
\text { cirrhosis, } \\
\text { cyclosporin }\end{array}$ & Yes & $8 \mathrm{~m}$ & Nil & Normal & Normal & - \\
\hline 4 & $30 / \mathrm{F}$ & $\begin{array}{l}\text { ARDS, } \\
\text { endocarditis, } \\
\text { sepsis }\end{array}$ & $\begin{array}{l}\text { MRSA } \\
\text { bacteremia }\end{array}$ & Yes & $12 \mathrm{~m}$ & Nil & Neurogenic changes $1^{\text {st }}$ dorsal Int. & Normal & - \\
\hline 5 & $36 / \mathrm{M}$ & $\begin{array}{l}\text { ARDS, } \\
\text { pancreatic } \\
\text { abscess }\end{array}$ & $\begin{array}{c}\text { DM II, } \\
\text { heterotopic } \\
\text { calcifications }\end{array}$ & No & $6 \mathrm{~m}$ & $\begin{array}{c}\text { Diffuse } \\
\text { weakness }\end{array}$ & $\begin{array}{l}\text { Conduction block peroneal nerve } \\
\text { at the knee, Neurogenic MUAP in } \\
\text { tibialis anterior; median } \\
\text { neuropathy at wrist }\end{array}$ & Normal & $\begin{array}{l}\text { Focal compressive } \\
\text { peronal palsy, CTS }\end{array}$ \\
\hline 6 & $59 / \mathrm{M}$ & $\begin{array}{l}\text { ARDS, KP tx } \\
\text { PCP }\end{array}$ & $\begin{array}{l}\text { DM II, } \\
\text { diabetic } \\
\text { polyneuropat } \\
\text { hy }\end{array}$ & Yes & $14 \mathrm{~m}$ & $\begin{array}{l}\text { Leg, hand } \\
\text { weakness }\end{array}$ & $\begin{array}{c}\text { Conducation block ulnar nerve } \\
\text { across elbow, and peroneal nerve } \\
\text { at the knee. Neurogenic MUAP of } \\
\text { ulnar and peroneal nerve } \\
\text { innervated muscles. }\end{array}$ & Abnormal & $\begin{array}{l}\text { Focal compressive ulnar } \\
\text { and peroneal palsy; } \\
\text { Polyneuropathy } \\
\text { (premorbid). }\end{array}$ \\
\hline 7 & $57 / \mathrm{F}$ & ARDS & Pneumonia & Yes & $11 \mathrm{~m}$ & Pain, Nu, T, LE & Normal & Normal & - \\
\hline 8 & $50 / \mathrm{F}$ & ARDS & - & No & $24 \mathrm{~m}$ & $\begin{array}{l}\text { Pain, } \mathrm{Nu}, \mathrm{T} \\
\text { hands and feet }\end{array}$ & Normal & Normal & - \\
\hline 9 & $52 / \mathrm{M}$ & $\begin{array}{l}\text { ARDS, ARF, } \\
\text { P.E., } \\
\text { pseudocyst }\end{array}$ & Pancreatitis & No & $18 \mathrm{~m}$ & $\begin{array}{l}\text { Foot drop, } \mathrm{Nu}, \mathrm{T} \\
\text { of legs }\end{array}$ & $\begin{array}{l}\text { Conduction block peroneal nerve } \\
\text { at the knee; neurogenic MUAP } \\
\text { tibialis anterior muscle }\end{array}$ & Abnormal & $\begin{array}{l}\text { Focal compressive } \\
\text { peroneal palsy }\end{array}$ \\
\hline 10 & $58 / \mathrm{M}$ & ARDS & - & No & $7 \mathrm{~m}$ & $\begin{array}{l}\text { Foot drop; weak } \\
\text { biceps, diffuse } \\
\text { pain }\end{array}$ & $\begin{array}{l}\text { Conduction block peroneal nerve } \\
\text { at the knee; neurogenic MUAP } \\
\text { tibialis anterior muscle }\end{array}$ & Normal & $\begin{array}{l}\text { Biopsy: Myopathy } \\
\text { Focal compressive } \\
\text { peroneal palsy; }\end{array}$ \\
\hline 11 & $41 / \mathrm{F}$ & $\begin{array}{l}\text { ARDS; DIC; } \\
\text { uterine rupture; } \\
\text { ARF }\end{array}$ & $\begin{array}{l}\text { DM II; } \\
\text { Hypothyroid }\end{array}$ & No & $5 \mathrm{~m}$ & $\begin{array}{l}\text { Foot drop, } \mathrm{Nu} \\
\text { legs and hands }\end{array}$ & $\begin{array}{l}\text { Conduction block peroneal nerve } \\
\text { at the knee; Neurogenic MUAP } \\
\text { peroneal muscles }\end{array}$ & Normal & $\begin{array}{l}\text { Biopsy: Myopathy } \\
\text { Focal compressive } \\
\text { peroneal palsy }\end{array}$ \\
\hline 12 & $47 / \mathrm{M}$ & $\begin{array}{c}\text { ARDS; } \\
\text { pneumothorax } \\
\text { ocular damage }\end{array}$ & - & Yes & $10 \mathrm{~m}$ & $\begin{array}{c}\text { Diffuse } \\
\text { weakness, pain } \\
\text { and Nu } \\
\text { shoulders and } \\
\text { arms }\end{array}$ & Normal & Normal & Biopsy: Myopathy \\
\hline 13 & $39 / \mathrm{M}$ & $\begin{array}{l}\text { ARDS, lung, } \\
\text { orthopedic } \\
\text { trauma }\end{array}$ & - & No & $9 \mathrm{~m}$ & $\begin{array}{l}\text { Leg weakness, } \\
\text { pain in stocking } \\
\text { distribution }\end{array}$ & Neurogenic MUAP in quadriceps & Normal & Lumbar radiculopathy \\
\hline 14 & $53 / \mathrm{F}$ & $\begin{array}{l}\text { ARDS, post } \\
\text { liver transplant }\end{array}$ & - & Yes & $6 \mathrm{~m}$ & $\begin{array}{l}\mathrm{Nu}, \mathrm{T} \text {, toes and } \\
\text { finger }\end{array}$ & Normal & Normal & - \\
\hline 15 & $45 / \mathrm{M}$ & $\begin{array}{l}\text { ARDS, } \\
\text { malaria, s. } \\
\text { typhi, ARF }\end{array}$ & DM II & No & $12 \mathrm{~m}$ & $\begin{array}{c}\text { Generalized } \\
\text { weakness, Nu T } \\
\text { hands and feet }\end{array}$ & Myopathic MUAP & Normal & Biopsy: Myopathy \\
\hline 16 & $47 / \mathrm{F}$ & ARDS, sepsis & - & No & $11 \mathrm{~m}$ & Pain, Nu, T,LE & Normal & Normal & - \\
\hline
\end{tabular}

Key: ARF: acute renal failure; CTS: carpal tunnel syndrome; DIC: disseminated intravascular coagulation; DM II: type 2 diabetes mellitus; Dx: diagnosis; F/U: length of follow-up; KP tx: kidney pancreas transplant; LE: lower extremities; MUAP: motor unit action potential; Nu: numbness; PCP: pneumocystis carinii pneumonia; PE: pulmonary embolism; T: tingling; VPT: vibration perception threshold

focal changes within the corresponding nerve distribution $(n=4$ in the Tibialis Anterior Muscle/peroneal, $n=2$ in the First Dorsal Interosseous Muscle/ulnar). Needle electromyographic examination of muscles affected by mononeuropathies revealed fibrillation potentials. In these patients, the electromyographic examination of other muscles was normal. The remaining six patients had normal EMG studies.

\section{Laboratory Tests}

Creatine kinase, thyroid stimulating hormone, lactate, complete blood count and erythrocyte sedimentation rate were normal in all 16 patients. All patients had normal nutritional status.

\section{Vibration Perception Threshold (VPT)}

Two patients had abnormal VPT.

\section{Muscle Biopsy}

All muscle biopsies were abnormal (Figure). The most frequent change was striking type II fiber atrophy, present in three of four biopsies, affecting IIa and II b fibers, and manifesting itself as narrow angulated fibers. In two patients, the atrophy was severe enough that many myofibers were reduced to clumps of myonuclei with little discernible cytoplasm. In all three such biopsies there was a mild excess of internal nuclei, ranging from $7-20 \%$ of fibers. In one biopsy, there was minimal structural change to the myofibers at the light microscopic level, although all four biopsies showed at least focal myofibrillary 

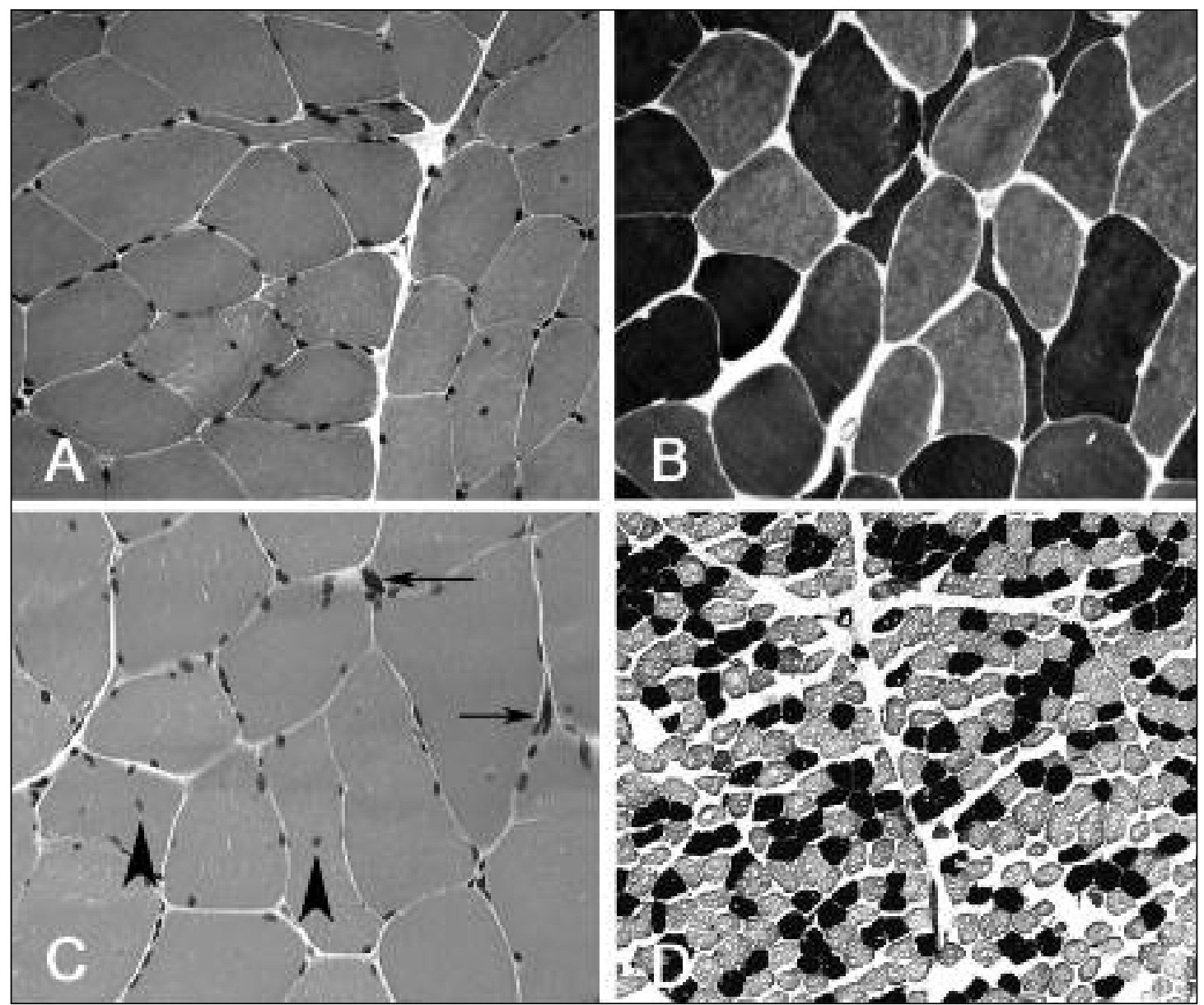

Figure: The histopathology of skeletal muscle in long term survivors of ARDS. A) demonstrates the angulated fibers typical of most of the biopsies (Cryostat section, Hematoxylin and Eosin x 200. B) On myosin ATPase staining at pH 9.4, the angulated fibers are almost wholly Type II fibers. C) Muscle biopsy demonstrating highly atrophic myofibers (arrows) consisting almost completely of nuclear clumps, and scattered internal nucle (arrowheads Hemalum Phloxine saffron $x$ 200). D) Low power Myosin ATP\{ASE, demonstrating a lack of frank grouping, but a loss of the normal checkerboard pattern (Myosin ATPase pH 9.4 x50).

disarray on electron microscopy. Frank fiber type grouping was not a feature of any biopsy. However, all biopsies showed some minimal loss of the normal checkerboard pattern, although this was not striking (Figure D). No patients demonstrated target fibers. No muscles tested were affected by compressive neuropathy.

\section{DISCUSSION}

We observed that compressive focal neuropathies, and a generalized, as yet unclearly characterized myopathy and/or neuropathy, occurred in a symptomatic subset of patients derived from a prospective cohort of ARDS survivors 6-24 months following discharge from the ICU. The long-term neuromuscular changes observed in our patients may be significant contributors to compromised exercise capacity as measured by distance walked in six minutes and reported as impaired health-related quality of life in ARDS survivors.

With the exception of the focal compressive neuropathies, there was imperfect correlation between the electrophysiology and the clinical and biopsy findings. For example, six of the patients had variable combinations of pain, numbness, tingling, diffuse weakness, cool extremities, and all had impaired exercise capacity, however their electrodiagnostic evaluations were normal. This clinical electrophysiological disparity may be on the basis of small fibre neuropathy or sampling error (the electrodiagnostic evaluation was standardized, and not tailored to individual patients' symptoms). Furthermore reduced exercise capacity does not have a specific electrodiagnostic correlate. We also cannot discount the possibility that some of the sensorimotor symptoms may have been psychogenic in origin, or 
from hitherto unknown dysfunction of the central nervous system.

Our muscle biopsy data show persistent structural changes after ARDS that may represent the residua of an ICU-acquired myopathy, an entity recently reported in this population. ${ }^{14}$ The abnormalities described are not exclusively attributable to disuse atrophy, or, in the case of the patients with diabetes, characteristic of histological changes that would be seen in the pre-morbid state. The biopsy findings however are non-specific and may be due a combination of muscle fibre type- 2 atrophy, resolving neurogenic atrophy or a low grade toxic myopathy. The absence of clear fibre type grouping argues against the meaningful presence of axonal neuropathy.

This study illustrates the high frequency of pressure palsies that can occur within a tertiary care ICU setting. Entrapment neuropathies represent a significant cause of long-term morbidity in ARDS survivors and should be preventable lesions. This highlights the ongoing need for more intensive surveillance of patient positioning and preventative measures in the ICU setting.

Our study was limited to a neuromuscular evaluation at or beyond six months following discharge from the ICU. Early nerve and muscle dysfunction might be hypothesized in ARDS survivors in light of data from other investigators. ${ }^{6,14,15}$ We were surprised that there was no electrodiagnostic evidence of longterm sensorimotor dysfunction attributable to critical illness polyneuropathy although some of the structural changes observed in muscle might be due to previous neuropathic disturbances. Biopsy from quadriceps (i.e a proximal muscle) may however be an insensitive test to reveal changes brought about by a length-dependent process that characterizes critical illness polyneuropathy. ${ }^{5}$

This case series has some important limitations. Only a small proportion of the ARDS cohort underwent a complete neuromuscular evaluation. We evaluated only the most symptomatic patients and these patients may not be representative of all ARDS survivors. We did not evaluate patients during their period of critical illness nor were we able to follow patients serially to understand the incidence and natural history of neuromuscular disease. Thus we do not have documentation of critical illness-induced polyneuropathy or myopathy during or soon after their period of critical illness. Finally, only a minority of the symptomatic patients underwent open muscle biopsy and therefore the interpretation of these findings is limited.

The present study suggests that persistent complaints of weakness resulting in long-term functional disability in ARDS survivors may be in part due to focal compressive neuropathy, and possibly an acquired myopathy. Our data supports the hypothesis that skeletal muscle may represent an important organ system that sustains a degree of irreversible damage as a result of a severe episode of critical illness. Accordingly, these patients may require open muscle biopsy for diagnosis since the pathological changes in muscle may not be evident on neurological or electrodiagnostic examinations. Although this study demonstrates persistent structural muscle changes in a small subset of symptomatic ARDS survivors, it is likely that long-term disability does not result from a single neuromuscular lesion, but rather that it is a multifactorial process.

\section{ACKNOWLEDGEMENTS}

The authors thank David Liang for assistance with reproduction of biopsy photographs.

\section{REFERENCES}

1. Milberg JA, Davis DR, Steinberg KP, Hudson LD. Improved survival of patients with acute respiratory distress syndrome (ARDS): 1983-1993. JAMA. 1995;273:306-9.

2. Davidson TA, Caldwell ES, Curtis JR, Hudson LD, Steinberg KP. Reduced quality of life in survivors of acute respiratory distress syndrome compared with critically ill control patients. JAMA. 1999;281:354-60.

3. Angus DC, Musthafa AA, Clermont G, Griffin MF, Linde-Zwirble WT, Dremsizov TT, et al. Quality-adjusted survival in the first year after the acute respiratory distress syndrome. Am J Respir Crit Care Med. 2001;163:1389-94.

4. Herridge MS, Cheung AM, Tansey CM, Matte-Martyn A, DiazGranados N, Al Saidi F, et al. One-year outcomes in survivors of the acute respiratory distress syndrome. $\mathrm{N}$ Engl J Med. 2003;348:683-93.

5. Zochodne DW, Bolton CF, Wells GA, Gilbert JJ, Hahn AF, Brown JD, et al. Critical illness polyneuropathy. A complication of sepsis and multiple organ failure. Brain. 1987;110 (Pt 4):819-41.

6. Coakley JH, Nagendran K, Honavar M, Hinds CJ. Preliminary observations on the neuromuscular abnormalities in patients with organ failure and sepsis. Intensive Care Med. 1993;19:323-8.

7. Latronico N, Fenzi F, Recupero D, Guarneri B, Tomelleri G, Tonin $\mathrm{P}$, et al. Critical illness myopathy and neuropathy. Lancet. 1996;347:1579-82.

8. Lacomis D, Giuliani MJ, Van Cott A, Kramer DJ. Acute myopathy of intensive care: clinical, electromyographic, and pathological aspects. Ann Neurol. 1996;40:645-54.

9. Lacomis D, Petrella JT, Giuliani MJ. Causes of neuromuscular weakness in the intensive care unit: a study of ninety-two patients. Muscle Nerve. 1998;21:610-17.

10. Helliwell TR, Coakley JH, Wagenmakers AJ, Griffiths RD, Campbell IT, Green CJ, et al. Necrotizing myopathy in criticallyill patients. J Pathol. 1991;164:307-14.

11. Ramsay DA, Zochodne DW, Robertson DM, Nag S, Ludwin SK. A syndrome of acute severe muscle necrosis in intensive care unit patients. J Neuropathol Exp Neurol. 1993;52:387-98.

12. De Jonghe B, Sharshar T, Lefaucheur JP, Authier FJ, DurandZaleski I, Boussarsar M, et al. Paresis acquired in the intensive care unit: a prospective multicenter study. JAMA. 2002; 288:2859-67.

13. Fletcher SN, Kennedy DD, Ghosh IR, Misra VP, Kiff K, Coakley $\mathrm{JH}$, et al. Persistent neuromuscular and neurophysiologic abnormalities in long-term survivors of prolonged critical illness. Crit Care Med. 2003;31:1012-16.

14. Bercker S, Weber-Carstens S, Deja M, Grimm C, Wolf S, Behse F, et al. Critical illness polyneuropathy and myopathy in patients with acute respiratory distress syndrome. Crit Care Med. 2005;33:711-15.

15. De Jonghe B, Sharshar T, Lefaucheur JP, Authier FJ, DurandZaleski I, Boussarsar M, et al. Paresis acquired in the intensive care unit: a prospective multicenter study. JAMA. 2002; 288:2859-67. 